\title{
EFFECT OF COW DUNG AS ORGANIC MANURE ON THE PRODUCTIVITY OF Cajanus cajan (L.) Millsp (Pigeon Pea)
}

\author{
Oktavius Yoseph Tuta Mago ${ }^{1}$ dan Yohanes Nong Bunga ${ }^{2}$ \\ Program Studi Pendidikan Biologi, Universitas Nusa Nipa \\ Jln. Kesehatan No. 3 Maumere, Nusa Tenggara Timur 86111, Indonesia \\ ${ }^{1}$ magoyotta@gmail.com, ${ }^{2}$ Uma.Sandy910@gmail.com
}

Doi: https://doi.org/10.31943/mangiferaedu.v5i1.91

Received: April 15, $2020 \quad$ Accepted: July 25, $2020 \quad$ Published: July 31, 2020

Citation: Mago, O. Y. T \& Bunga, Y. N. (2020). Effect of Cow Dung as Organic Manure on the Productivity of Cajanus cajan (L.) Millsp (Pigeon pea). Jurnal Mangifera $E d u, 5(1), 8-17$.

\begin{abstract}
Cajanus cajan (L.) Millsp is a local plant which not fully utilized by people in Sikka. This plant has a high nutrient content besides a potential of traditional medicine. This research is aimed to examine the effect of organic fertilizer on Cajanus cajan (L.) Millsp productivity. This research was carried out in Geliting village of Sikka District from May to December 2019. Cow dung and agricultural by-product were used as organic fertilizers. Before applied to the plant, these ingredients were mixed and anaerobically fermented in 30 days. The fertilizer dosage are as follows, $0 \mathrm{~kg} / \mathrm{m}^{2}$ (control), $0,5 \mathrm{~kg} / \mathrm{m}^{2}, 1$ $\mathrm{kg} / \mathrm{m}^{2}, 1,5 \mathrm{~kg} / \mathrm{m}^{2}, 2 \mathrm{~kg} / \mathrm{m}^{2}$, and 2,5 kg/m . Randomized Block Design was used and examined variables were the flowering time, number of pod and wet weight of seed. The result showed that there was no effect of organic fertilizer on Cajanus cajan (L.) Millsp productivity.
\end{abstract}

Keywords: Cajanus cajan (L.) Millsp, organic fertilizer, productivity

\section{ABSTRAK}

Cajanus cajan (L.) Millsp merupakan tanaman lokal yang belum dimanfaatkan secara maksimal oleh masyarakat Kabupaten Sikka. Tanaman ini, selain memiliki kandungan gizi tinggi, juga berkhasiat sebagai obat tradisional. Penelitian ini bertujuan untuk mengkaji pengaruh pemberian pupuk organik terhadap produktivitas Cajanus cajan (L.) Millsp. Penelitian ini dilaksanakan di Desa Geliting, Kabupaten Sikka pada bulan Mei - Desember 2019. Pupuk organik yang digunakan adalah kotoran sapi dan limbah pertanian yang telah difermentasi secara anaerob selama 30 hari dengan pemberian dosis $0 \mathrm{~kg} / \mathrm{m}^{2}$ (kontrol), $0,5 \mathrm{~kg} / \mathrm{m}^{2}, 1 \mathrm{~kg} / \mathrm{m}^{2}, 1,5 \mathrm{~kg} / \mathrm{m}^{2}, 2 \mathrm{~kg} / \mathrm{m}^{2}$, dan $2,5 \mathrm{~kg} / \mathrm{m}^{2}$. Rancangan acak kelompok $(R A K)$ diterapkan dalam penelitian ini dan variabel produktivitas yang diukur adalah waktu berbunga, jumlah polong dan berat basah biji. Hasil analisis data menggunakan Minitab 18.0 menunjukkan bahwa tidak terdapat pengaruh pemberian pupuk organik kotoran sapi terhadap produktivitas Cajanus cajan (L.) Millsp.

Kata Kunci: Cajanus cajan (L.) Millsp, produktivitas, pupuk organik 


\section{PENDAHULUAN}

Cajanus cajan (L.) Millsp (Pigeon pea) merupakan tumbuhan Leguminoceae yang ditanam sebagai tanaman sela pada areal pertanian. Biji dan daunnya merupakan sumber gizi serta sumber obat tradisional bagi masyarakat. Penggunaannya semakin luas, karena selain sebagai masakan yang dicampur dengan nasi, juga dapat diolah sebagai bahan baku pembuatan tempe dan kecap (Andriana, 2014; Haliza et al., 2016).

Tumbuhan Cajanus cajan (L.) Millsp tergolong tanaman lokal dengan nilai ekonomis yang cukup tinggi. Meski demikian, tumbuhan ini membutuhkan penanganan yang serius karena petani di Kabupaten Sikka lebih memilih menanamnya sebagai tanaman sela. Hasil penelusuran pada laman BPS Nusa Tenggara Timur (https://ntt.bps.go.id), tidak menemukan Cajanus cajan (L.) Millsp sebagai salah satu objek survei. Hal ini menunjukkan bahwa pigeon pea kurang mendapat perhatian para stakeholder.

Sistem pertanian lahan kering dengan pola tumpang sari dapat menyebabkan penurunan kandungan unsur hara pada tanah. Jika Cajanus cajan ditanam secara terus menerus dengan sistem ini, kandungan unsur hara dalam tanah menjadi tidak cukup untuk mendukung pertumbuhannya yang optimal. Cajanus cajan membutuhkan hara nitrogen, kalium dan fosfor dalam jumlah besar. Hal ini disebabkan karena kacang-kacangan merupakan jenis tanaman yang kaya energi yang terdiri atas mineral, lemak, protein dan vitamin (Taufiq et al., 2020; Sekhon et al., 2018). Sementera itu, ketersediaan hara mikro seperti molybdenum (Mo), zinc ( $\mathrm{Zn})$, boron (Bo) dan besi (Fe) juga sangat mempengaruhi produktifitas Cajanus cajan (Ray et al., 2015).

Perbaikan kondisi tanah yang mengalami kekurangan hara dapat dilakukan dengan pemberian pupuk organik (Zulkifli \& Herman, 2012). Perlakuan ini diharapkan dapat meningkatan fase pertumbuhan dan produksi Cajanus cajan (L.) Millsp. Pupuk organik adalah pupuk yang dihasilkan dari biomassa tanaman, hewan serta zat sisa metabolismenya. Biomassa dan sisa metabolisme ini tidak secara langsung digunakan, tetapi terlebih dahulu harus mengalami proses perombakan atau pengomposan menjadi senyawa yang lebih sederhana dengan bantuan mikroorganisme. Pupuk organik berperan dalam perbaikan kualitas tanah seperti perbaikan struktur, aerasi dan meningkatkan kapasitas untuk menahan air. Pupuk organik juga menyediakan hara makro esensial yang dibutuhkan oleh tumbuhan seperti nitrogen $(\mathrm{N})$, fosfor $(\mathrm{P})$ dan kalium $(\mathrm{K})$. Selain itu, terdapat pula hara mikro seperti kalsium, magnesium, belerang, natrium, besi dan tembaga (Hapsari, 2013).

Salah satu bahan baku pupuk organik yang sering digunakan adalah kotoran sapi. Pupuk organik padat kotoran sapi mengandung unsur N, P dan K dalam jumlah yang cukup 
tinggi (Islam et al., 2010). Dengan kandungan hara makro yang tinggi, pupuk organik ini diharuskan mampu menyediakan nutrisi yang dibutuhkan oleh Cajanus cajan. Penduduk desa Geliting selain bercocok tanam, juga memiliki banyak ternak sapi sehingga ketersediaan bahan baku pupuk organik cukup memadai. Dalam penelitian ini bahan dasar pupuk organik yang digunakan adalah kotoran sapi, daun, dan batang jagung yang sudah kering. Batang dan daun jagung mengandung hara makro nitrogen, fosfor, dan kalium serta beberapa hara mikro seperti kalsium, magnesium, besi, mangan, dan zinc (Ferreira et al., 2014; Magalhães et al., 2016). Pemberian batang dan daun jagung diharapkan dapat menambah ketersediaan unsur hara dalam pupuk organik. Penelitian ini bertujuan untuk mengkaji pengaruh pemberian pupuk organik kotoran sapi terhadap produktivitas Cajanus cajan. Parameter produktivitas yang diamati adalah waktu berbunga, jumlah polong, dan berat biji.

Nata et al. (2020), melaporkan bahwa penggunaan pupuk organik kotoran sapi dengan dosis 20 ton/ha $\left(2 \mathrm{~kg} / \mathrm{m}^{2}\right)$ menghasilkan jumlah polong kacang panjang tertinggi yaitu 70 polong per tanaman. Sedangkan dengan dosis 5 ton/ha $\left(0,5 \mathrm{~kg} / \mathrm{m}^{2}\right)$ hanya menghasilkan 56 polong per tanaman. Penelitian ini juga menyatakan bahwa berat biji terbesar dihasilkan oleh tanaman yang diberikan pupuk dengan dosis 20 ton/ha, yaitu sebesar 5,3 ton/ha. Tampubolon (2011), menyatakan bahwa dosis 20 ton/ha kompos biogas dari kotoran sapi mampu menghasilkan 1,083 ton/ha kacang kedelai. Dua penelitian ini menunjukkan bahwa pupuk organik kotoran sapi memiliki efek yang baik dalam meningkatkan produktivitas tanaman kacang-kacangan.

Hasil observasi pada beberapa tempat produksi tempe di Kabupaten Sikka menunjukkan bahwa tingkat kebergantungan pada kacang kedelai yang didatangkan dari luar Kabupaten Sikka masih sangat tinggi. Produksi kedelai lokal tidak mampu mengimbangi kebutuhan pasar. Kesenjangan ini dapat dimanfaatkan oleh petani dengan meningkatkan hasil produksi Cajanus cajan (L.) Millsp sebagai pengganti kacang kedelai. Utami et al. (2015); Primiani \& Pujiati, (2017); Rahayu \& Roosmarinto, (2017); Ariviani et al. (2018), menyatakan bahwa Cajanus cajan (L.) Millsp memiliki kandungan senyawa kimia yang baik untuk kesehatan. Meskipun demikian, penelitian tersebut belum membahas bagaimana upaya pelestarian tanaman pangan lokal, pemenuhan kebutuhan benih, dan industri pigeon pea. Hasil penelitian ini diharapkan memberikan informasi tentang pemanfaatan pupuk organik untuk produktivitas Cajanus cajan (L.) Millsp kepada masyarakat desa Geliting. 


\section{METODOLOGI PENELITIAN}

\section{Pembuatan pupuk organik}

Pembuatan pupuk organik dimulai dengan mengumpulkan kotoran sapi sebanyak 20 $\mathrm{kg}$, daun, dan batang jagung. Daun dan batang jagung dicincang sampai halus lalu dicampur dengan kotoran sapi dengan perbandingan 1:2. Bahan tersebut dipercik dengan air bersih 5 liter dan air gula 1 liter, selanjutnya ditutup rapat dengan terpal selama 30 hari untuk proses fermentasi secara anaerob (Bustami, 2012).

\section{Persiapan bedeng percobaan}

Penelitian dilaksanakan di kebun rakyat Desa Geliting Kecamatan Kewapante, Kabupaten Sikka dari bulan Mei 2019 - Desember 2019. Persiapan lahan dilakukan dengan cara dipacul dan dibuat dalam bentuk bedeng sebanyak 6 bedeng. Bedeng yang disiapkan berukuran panjang $10 \mathrm{~m}$ dan lebar 1,2 $\mathrm{m}$ dan tinggi bedeng $20 \mathrm{~cm}$, sedangkan jarak antar bedeng $1 \mathrm{~m}$. Keenam bedeng disiram air hingga lembab lalu ditutup dengan plastik mulsa yang telah diberi lubang pada bagian tempat penanaman benih.

\section{Penanaman benih Cajanus cajan}

Pemilihan benih Cajanus cajan (L.) Millsp terbaik dilakukan dengan cara merendam benih dalam air selama 15 menit. Benih yang tenggelam kemudian dipilih untuk ditanam sebanyak 3 benih pada posisi berjarakan dengan kedalaman $\pm 2 \mathrm{~cm}$. Jarak antar lubang penanaman adalah $\pm 40 \mathrm{~cm}$.

\section{Rancangan penelitian}

Penelitian ini menggunakan Rancangan Acak Kelompok (RAK) dengan taraf 6 dosis pupuk organik kotoran sapi yakni; $\mathrm{P} 0=$ tanpa pupuk (kotrol), $\mathrm{P} 1=\operatorname{dosis} 0,5 \mathrm{~kg} / \mathrm{m}^{2}, \mathrm{P} 2=1$ $\mathrm{kg} / \mathrm{m}^{2}, \mathrm{P} 3=1,5 \mathrm{~kg} / \mathrm{m}^{2}, \mathrm{P} 4=2 \mathrm{~kg} / \mathrm{m}^{2}, \mathrm{P} 5=2,5 \mathrm{~kg} / \mathrm{m}^{2}$. Setiap perlakuan diulang dalam enam bedeng/kelompok sehingga terdapat 36 unit percobaan.

\section{Pemupukan dan perawatan}

Pemupukan dilakukan ketika tanaman telah berumur 14 hari setelah tanam (hst). Pemberian pupuk organik kotoran sapi dilakukan dengan cara menaburkan pupuk pada lubang sedalam $\pm 20 \mathrm{~cm}$ di sekeliling tanaman dengan radius $\pm 5 \mathrm{~cm}$ dari batang (Bunga, 2018).

Penyiraman dilakukan dua kali seminggu sedangkan penyiangan dilakukan dengan mencabut gulma ketika mulai tumbuh dekat tanaman. Penjarangan dilakukan ketika tanaman telah mencapai ketinggian $\pm 15 \mathrm{~cm}$ dengan menyisakan satu tanaman sampel. Penjarangan dilakukan pada sore hari. 


\section{Pengukuran variable pengamatan}

Variabel yang diamati adalah waktu berbunga, jumlah polong dan berat basah biji Cajanus cajan (L.) Millsp. Ketiga variabel ini diamati pada waktu yang berbeda. Waktu berbunga adalah waktu yang dibutuhkan tanaman dari penanaman sampai menghasilkan pembungaan pertama. Satuan waktu berbunga yang dihitung adalah hari setelah tanam (hst).

Jumlah polong dihitung saat pemanenan polong kering yang dihitung dari tiap tanaman. Berat biji ditimbang setelah dipisahkan dari polong dan dikeringkan di bawah sinar matahari. Satuan berat biji adalah gram $(\mathrm{g})$.

\section{Analisis data}

Data yang diperoleh dianalisis dengan general linier model menggunakan software Minitab 18.0 dengan taraf 5\% untuk mengetahui ada tidaknya pengaruh perlakuan terhadap respon.

\section{HASIL DAN PEMBAHASAN}

Hasil analisis data menunjukkan bahwa tidak terdapat pengaruh pemberian pupuk organik terhadap produktivitas Cajanus cajan (L.) Millsp. Pengaruh pemupukan tidak tampak pada ketiga variabel yang diukur yakni waktu berbunga, jumlah polong dan berat biji.

\section{Waktu berbunga Cajanus cajan (L.) Millsp}

Rata-rata waktu yang diperlukan Cajanus cajan (L.) Millsp untuk berbunga berkisar antara 87-104 hari setelah tanam (hst). Waktu berbunga dihitung sejak tanaman ditanam hingga pembungaan pertama untuk tiap tanaman. Pada umumnya Cajanus cajan membutuh waktu sekitar 65 - 80 hari setelah tanam untuk menghasilkan bunga pertama (Cook et al., 2005) . Hasil yang diperoleh menunjukkan Cajanus cajan mengalami keterlambatan dalam menghasilkan bunga. Waktu berbunga Cajanus cajan (L.) Millsp dapat diamati pada Tabel 1.

Tabel 1. Waktu Berbunga Cajanus cajan (L.) Millsp

\begin{tabular}{ccccccc}
\hline Perlakuan & $\begin{array}{c}\text { P0 } \\
\text { (kontrol) }\end{array}$ & P1 & P2 & P3 & P4 & P5 \\
\hline Jumlah & 90,0 & 95,7 & 87,2 & 95,5 & 104,8 & 96,3 \\
\hline
\end{tabular}

Keterangan: satuan: hari setelah tanam (hst)

Hasil analisis data menunjukkan tidak ada pengaruh pemberian pupuk organik terhadap waktu berbunga Cajanus cajan (L.) Millsp. Hal ini ini diduga karena ketersediaan hara esensial untuk pembentukan bunga tidak maksimal. Fikdalillah et al. (2016), 
menyatakan bahwa kandungan unsur $\mathrm{P}$ dalam kotoran sapi hanya 0,09\%, padahal unsur ini memiliki peranan penting dalam pembentukan bunga pada tanaman. Fosfor yang terserap merupakan komponen penting dalam menyusun senyawa yang berperan dalam transfer energi (ATP dan nukleoprotein lain), sistem informasi genetik (DNA dan RNA), membran sel (fosfolipid) dan fosfoprotein.

Kondisi ini diduga dipengaruhi oleh penanaman dilaksanakan pada musim kemarau. Pada musim kemarau, daerah Kabupaten Sikka dan Provonsi Nusa Tenggara Timur umumnya mengalami kekurangan air. Peneliti telah berupaya untuk melakukan penyiraman dengan air secukupnya pada setiap tanaman. Kekurangan air yang dialami oleh tanaman akan berpengaruh kepada proses penyerapan nutrisi dalam tanah sehingga lama waktu pembentukan bunga tidak terdapat perbedaan. Anggraini et al. (2015), melaporkan bahwa interval penyiraman yang lama akan mempengaruhi laju fotosintesis, transpirasi dan konduktasi stomata serta pertumbuhan akan semakin rendah. Laju fotosintesis yang terganggu diyakini akan menghambat pendistribusian hasil fotosintesis ke seluruh tubuh tumbuhan sehingga proses pembentukan bunga turut dipengaruhi. Cajanus cajan merupakan tanaman yang tahan terhadap kondisi lingkungan kering karena sistem perakaran yang dalam. Tanaman ini bisa bertahan hidup dalam waktu enam bulan kering (Cook et al., 2005). Namun, proses pembungaan akan terhambat dan biji yang dihasilkan akan berkurang (Singh et al., 2010).

\section{Jumlah Polong Cajanus cajan (L.) Millsp}

Variabel yang diamati selanjutnya adalah jumlah polong. Jumlah polong dihitung setelah melakukan pemanenan. Berikut ini merupakan tabel hasil pengamatan variabel jumlah polong (Tabel 2).

Tabel 2. Rerata Jumlah Polong Cajanus cajan (L.) Millsp (Buah) untuk Setiap Dosis Pupuk

\begin{tabular}{ccccccc}
\hline $\begin{array}{c}\text { Dosis Pupuk } \\
\text { Organik }\end{array}$ & $\begin{array}{c}\mathbf{0} \mathbf{~ k g} \\
\text { (kontrol) }\end{array}$ & $\mathbf{0 , 5} \mathbf{~ k g}$ & $\mathbf{1} \mathbf{~ k g}$ & $\mathbf{1 , 5} \mathbf{~ k g}$ & $\mathbf{2} \mathbf{~ k g}$ & $\mathbf{2 , 5} \mathbf{~ k g}$ \\
\hline Jumlah & 70,17 & 36,17 & 88,67 & 40,17 & 52,17 & 57,5 \\
\hline
\end{tabular}

Ket: satuan: buah

Rata-rata jumlah polong tanaman Cajanus cajan (L.) Millsp berkisar antara 40-89 buah polong. Hasil analisis General Linear Model menunjukkan bahwa tidak terdapat perbedaan yang signifikan jumlah polong tanaman (P 0,69>0,05) yang diberi perlakuan pupuk. Kondisi ini diduga dipengaruhi oleh kurangnya unsur NPK pada kotoran sapi. Meskipun terdapat daun dan batang jagung di dalam bahan baku pupuk organik sebagai penambah hara esensial, kebutuhan hara bagi tanaman Cajanus cajan mungkin belum cukup. Hal ini diduga karena penguraian bahan baku pupuk belum berlangsung dengan sempurna. 
Waktu fermentasi anaerob pupuk dalam penelitian ini adalah 30 hari, sedangkan Sukamta et al. (2017), menyatakan bahwa pembuatan pupuk organik kotoran sapi ditambahkan bioaktivator membutuhkan waktu selama 2 bulan untuk mendapatkan hasil yang maksimal. Mulyani \& Kartasapoetra, (2002) juga menyatakan bahwa meskipun pupuk organik dari kotoran sapi memiliki kandungan N (0,29\%), P (0,17\%), dan K (0,35\%), Pupuk ini tergolong pupuk yang penguraiannya berjalan cukup lambat.

Tan (2009), menyatakan bahwa unsur NPK pada kotoran sapi berturut-turut 0,53\%, $0,35 \%$, dan $0,41 \%$. Unsur $\mathrm{N}$ berperan dalam proses sintesis karbohidrat, unsur $\mathrm{P}$ berperan dalam proses pembentukan buah dan unsur $\mathrm{K}$ berperan dalam peningkatan kualitas buah (Sutejo \& Kartasapoetra, 1990). Ketersediaan unsur hara NPK yang dapat diserap oleh tanaman dapat memberikan pengaruh pada tanaman secara keseluruhan termasuk pembentukan polong. Bunga (2018), membuktikan bahwa unsur NPK berperan dalam pembentukan polong kacang tanah.

\section{Berat Biji Cajanus cajan (L.) Millsp}

Rata-rata berat biji tanaman Cajanus cajan (L.) Millsp berkisar antara 31-52 gram. Analisis General Linear Model menunjukkan bahwa tidak terdapat perbedaan yang signifikan pada berat biji (P 0,71>0,05) yang diberi perlakuan pupuk. Hasil perhitungan berat biji disajikan pada Tabel 3.

Tabel 3. Rerata Berat Biji Cajanus cajan untuk Setiap Dosis Pupuk Organik

\begin{tabular}{ccccccc}
\hline $\begin{array}{c}\text { Dosis } \\
\text { Pupuk } \\
\text { Organik }\end{array}$ & $\begin{array}{c}\mathbf{0 ~ k g} \\
\text { (kontrol) }\end{array}$ & $\mathbf{0 , 5} \mathbf{~ k g}$ & $\mathbf{1 ~ k g}$ & $\mathbf{1 , 5} \mathbf{~ k g}$ & $\mathbf{2} \mathbf{~ k g}$ & $\mathbf{2 , 5} \mathbf{~ k g}$ \\
\hline Jumlah & 38,8 & 19,4 & 51,1 & 21,3 & 31,8 & 34,8 \\
\hline
\end{tabular}

Keterangan: satuan: gram (g)

Jumlah biji yang dihasilkan tanaman Cajanus cajan (L.) Millsp bervariasi, mulai dari satu biji hingga enam biji dalam setiap polong. Ada pula beberapa polong hampa yang dihasilkan oleh tanaman. Hal ini menandakan bahwa unsur $\mathrm{N}$ tidak terserap dengan baik oleh tanaman atau kadar $\mathrm{N}$ dalam tanah sangat terbatas. Hal ini diduga karena waktu fermentasi yang singkat, membuat pelepasan unsur hara dari bahan organik belum terjadi secara maksimal. Padahal hara makro sangat dibutuhkan dalam pertumbuhan dan produktivitas tanaman. Unsur hara $\mathrm{N}$ memiliki peranan dalam pembentukan polong dan pembentukan biji tanaman. Nitrogen yang terserap oleh tanaman akan tertimbun pada batang dan daun setelah polong terbentuk. Nitrogen selanjutnya tersimpan pada kulit polong dan diserap ke dalam biji pada fase pengisin biji (Puspasari et al., 2018). 
Fosfor merupakan elemen mineral penting untuk perkembangan biji kacangkacangan. Hara ini berperan dalam pembentukan akar, sintesis fosfat dan fosfoprotein dan berpartisipasi dalam pengikatan dan pelepasan energi (Odeny, 2007). Unsur hara P juga dapat memacu dan memperkuat masa generatif suatu tanaman dan meningkatkan hasil bijibijian, sehingga jumlah dan berat biji dapat bertambah (Widodo, 2019). Kekurangan hara ini dapat mengakibatkan penurunan hasil panen pada tanaman tertentu, termasuk Cajanus cajan.

Selain hara makro, hara mikro juga turut memberikan pengaruh penting bagi pembentukan polong dan biji kacang-kacangan. Ray et al. (2015), menyatakan bahwa ketersediaan hara mikro seperti molybdenum (Mo), zinc ( $\mathrm{Zn})$, boron (Bo) dan besi (Fe) sangat mempengaruhi produktifitas Cajanus cajan. Cajanus cajan dalam penelitian ini mungkin mengalami kekurangan hara mikro, sehingga pembentukan polong dan biji tidak terjadi dengan optimal.

\section{SIMPULAN}

Perlakuan pemberian pupuk organik kotoran sapi tidak memberikan pengaruh pada produktivitas Cajanus cajan (Pigeon pea). Hal ini dilihat dari pengukuran variabel waktu berbunga, jumlah polong dan berat biji yang dihasilkan. Ketiga variabel ini menunjukkan hasil yang tidak berbeda antara satu perlakuan dengan perlakuan lainnya.

\section{UCAPAN TERIMA KASIH}

Penulis menyampaikan limpah terima kasih kepada Kemenristek Dikti yang telah mendukung penelitian ini baik secara moral maupun materil.

\section{DAFTAR PUSTAKA}

Andriana, D. (2014). Pengaruh Substitusi Kacang Gude(Cajanus cajan) Terhadap Kadar Protein dan Daya Terima Kecap Kedelai. Unnes Journal of Public Health, 3(3), 1-8. https://doi.org/https://doi.org/10.15294/ujph.v3i3.3538

Anggraini, N., Faridah, E., \& Indrioko, S. (2015). Pengaruh Cekaman Kekeringan Terhadap Perilaku Fisiologis dan Pertumbuhan Bibit Black Locust (Robinia pseudoacacia). Jurnal Ilmu Kehutanan, 9(1), 40-56.

Ariviani, S., Affandi, D. R., Listyaningsih, E., \& Handajani, S. (2018). The potential of pigeon pea (Cajanus cajan) beverage as an anti-diabetic functional drink. The 2nd International Symposium on Food and Agro-Biodiversity, 12051-12054.

Bunga, Y. N. (2018). Respon Produksi Kacang Tanah (Arachis hypogaea L.) Akibat 
Jurnal Mangifera Edu, Volume 5, Nomor 1, Juli 2020, 8-17

Penggunaan Pupuk NPK dan Pupuk Mikroba. Biota, 11(2), 146-157.

Bustami. 2012. Pembuatan Pupuk Organik Berbahan Limbah Sapi. Jambi: Balai Pengkajian Teknologi Pertanian.

Cook, B. G., Pengelly, B. C., Brown, S. D., Donnelly, J. L., Eagles, D. A., Franco, M. A., Hanson, J., Mullen, B. F., Partridge, I. J., \& Peters, M. (2005). Tropical Forages: an interactive selection tool. Tropical Forages: An Interactive Selection Tool.

Ferreira, C. F., Motta, A. C. V, Barbosa, J. Z., dos Santos, N. Z., Prior, S., \& Gabardo, J. (2014). Maize (Zea mays L) cultivars nutrients concentration in leaves and stalks. Maydica, 59(1), 65-71.

Fikdalillah, F., Basir, M., \& Wahyudi, I. (2016). Pengaruh pemberian pupuk kandang sapi terhadap serapan fosfor dan hasil tanaman sawi putih (Brassica pekinensis) pada Entisols sidera. AGROTEKBIS: E-JURNAL ILMU PERTANIAN, 4(5), 491-499.

Haliza, W., Purwani, E. Y., \& Thahir, R. (2016). Pemanfaatan kacang-kacangan lokal sebagai substitusi bahan baku tempe dan tahu. Buletin Teknologi Pasca Panen, 3(1), 18.

Hapsari, A. Y. (2013). Kualitas dan Kuantitas Kandungan Pupuk Organik Limbah Serasah dengan Inokulum Kotoran Sapi Secara Semianaerob (p. 8). Universitas Muhammadiyah Surakarta.

Islam, M. R., Rahman, S. M. E., Rahman, M. M., Oh, D. H., \& Ra, C. S. (2010). The effects of biogas slurry on the production and quality of maize fodder. Turkish Journal of Agriculture and Forestry, 34(1), 91-99.

Magalhães, A. G., Rolim, M. M., Duarte, A. de S., Silva, G. F. da, Bezerra Neto, E., \& Pedrosa, E. M. R. (2016). Macronutrient and sodium content in maize plants under cassava wastewater fertilization. Revista Brasileira de Engenharia Agrícola $e$ Ambiental, 20(3), 215-222.

Mulyani, M., \& Kartasapoetra, A. G. (2002). Pupuk dan Cara Pemupukan. Rineka Cipta, Jakarta, 175.

Nata, I. N. I. B., Dharma, I. P., \& Wijaya, I. K. A. (2020). Pengaruh Pemberian Berbagai Macam Pupuk terhadap Pertumbuhan dan Hasil Tanaman Gumitir (Tagetes erecta L.). Jurnal Agroekoteknologi Tropika ISSN, 9(2), 115-124.

Odeny, D. A. (2007). The Potential of Pigeonpea (Cajanus cajan (L.) Millsp.) in Africa. Natural Resources Forum, 31(4), 297-305.

Primiani, C. N., \& Pujiati, P. (2017). Profil Fitoestrogen Kacang Gude (Cajanus cajan) dalam Darah, Urin dan Feses pada Tikus Putih Betina. Jurnal Mipa, 40(1), 14-19.

Puspasari, R., Karyawati, A. S., \& Sitompul, S. M. (2018). Pembentukan Polong dan Hasil Tanaman Kedelai (Glycine max (L.) Merril) dengan Pemberian Nitrogen pada Fase Generatif. Jurnal Produksi Tanaman, 6(6), 1096-1102. 
Rahayu, M., \& Roosmarinto, R. (2017). Kajian Aktivitas Antikanker Ekstrak Daun Gude (cajanus cajan) Terhadap Sel Kanker Kolon Secara in Vitro. Jurnal Teknologi Laboratorium, 6(1), 31-38.

Ray, S., De, B., \& Hazari, S. (2015). Growth and Productivity as Influenced by Nutrient Management Practices on Pigeon pea [Cajanus cajan (L.) Millsp.] in Upland Alfisols of Tripura. SAARC Journal of Agriculture, 13(1), 123-134.

Sekhon, F. S., Singh, T., \& Saini, K. S. (2018). Productivity and nutrient uptake of pigeonpea (Cajanus cajan) in pigeonpea based intercropping systems as influenced by planting pattern and nutrients levels applied to intercrops. Indian Journal of Agricultural Sciences, 88(10), 1582-1586.

Singh, G., Aggarwal, N., \& Ram, H. (2010). Effect of Row Spacing and Weed Management Practices on Weeds, Growth and Yield of Pigeonpea [Cajanus cajan (L.) Millsp.]. Indian Journal of Weed Science, 42(3and4), 241-243.

Sukamta, S., Shomad, M. A., \& Wisnujati, A. (2017). Pengelolaan Limbah Ternak Sapi Menjadi Pupuk Organik Komersial di Dusun Kalipucang, Bangunjiwo, Bantul, Yogyakarta. BERDIKARI: Jurnal Inovasi Dan Penerapan Ipteks, 5(1), 1-10.

Sutejo, M. M., \& Kartasapoetra, A. G. (1990). Pupuk dan cara pemupukan. Rineka Cipta.

Tampubolon, G. (2011). Pengaruh Pemberian Kompos Sisa Biogas Kotoran Sapi Terhadap Perbaikan Beberapa Sifat Fisik Ultisol dan Hasil Kedelai (Glycine max (L.) Merill). Jurnal Hidrolitan, 2(3), 103-114.

Tan, K. H. (2009). Environmental soil science. CRC Press.

Taufiq, A., Kristiono, A., Wijanarko, A., Rahmianna, A. A., Iswanto, R., \& Riyanto, S. A. (2020). Adaptabilitas Varietas-varietas Unggul Kacang Tanah pada Tanah Salin. Jurnal Penelitian Pertanian Tanaman Pangan, 4(1), 43-51. https://doi.org/http://dx.doi.org/10.21082/jpptp.v4n1.2020.p43-51

Utami, R., Widowati, E., \& Purwandari, Y. W. (2015). Karakteristik Kaldu Nabati Kedelai Hitam (Glycine soja), Kacang Gude (Cajanus cajan, Mills) dan Biji Saga (Adenanthera pavonina, Linn) melalui Fermentasi Koji Moromi. Jurnal Teknologi Hasil Pertanian, $8(1)$.

Widodo, R. W. (2019). The Effect of Chicken Manure Dose on Growth and Yield of Big Red Beans (Phaseolus vulgaris. L). JURNAL PERTANIAN, 10(2), 71-79.

Zulkifli, Z., \& Herman, H. (2012). Respon Jagung Manis (Zea mays saccharata Stut) Terhadap Dosis dan Jenis Pupuk Organik. Jurnal Agroteknologi, 2(2), 25-28. https://doi.org/http://dx.doi.org/10.24014/ja.v2i2.125 